\title{
AN UNRECORDED COPY OF WYNKYN DE WORDE'S 1506 EDITION OF CONTEMPLATIONS OF THE DREAD AND LOVE OF GOD
}

The late medieval devotional prose work Contemplations of the Dread and Love of God (also known as Fervor Amoris) was printed by Wynkyn de Worde in 1506 (STC 21259) and reprinted by him [1519?] (STC 21260). De Worde attributed the text (incorrectly) to Richard Rolle.

Only three copies of the first edition have hitherto been known: in the British Library, in the John Rylands University Library in Manchester, and in Durham University Library. ${ }^{1}$ This degree of rarity makes my identification of a further copy of some importance. There is one in the Russell Library at St Patrick's College, Maynooth (now part of the National University of Ireland). This is a complete copy, and in generally good condition, if rather dirty and torn in places. The bottom of the final page is damaged, but the colophon

\footnotetext{
${ }^{1}$ The revised STC records an additional copy in the collection of the late Paul Mellon of Upperville, Virginia. But this seems to be an error. It is not among the early English books from his collection now in the Mellon Center for British Art at Yale University; this copy has now been removed from the online STC records as a result of my enquiries. Mellon did own a copy of the [1519?] edition now at Yale, for which see Fifty-five Books Printed Before 1525, Representing the Works of England's First Printers: An Exhibition from the Collection of Paul Mellon, January 17-March 3, 1968 (New York, 1968), 28 (no. 24), and this fact may have led to some confusion when his collection was privately owned.
} 
with the date remains intact: 'Enprynted at London in fletestrete in pe sygne of the sonne By Wynkyn de Worde. Anno dni M CCCCC.vi.'. The edition is bound at the end of RB 362, after a collection of late seventeenth- and early eighteenth-century items, eighteen in total, which were printed in London between 1685 and 1720. These have been bound together since the nineteenth century.

University of St Andrews 